\title{
How demography affects asset characteristics in Hungary
}

\author{
Alexandra Posza - Vivien Csapi \\ University of Pécs
}

\section{THE AIMS OF THE PAPER}

The population factor in general influences most of the global megatrends. While it was considered one ofthe major driving forces for economic growth in the 20th century, it has become the greatest risk factor forthe socio-economic landscape. Hungary is experiencing one of the fastest demographic transitions in Europe. Due to the continued extension of longevity and the steep decline in fertility rate, the size and percentage of the elderly population (i.e., aged 65 and above) rapidly increased during the last decades. The paper aims to examine whether population ageing has an effect on asset prices in Hungary.

\section{METHODOLOGY}

The life cycle theory for Hungary was applied while exploring the quantitative link between population structures and asset prices, particularly on stock and bonds. In this study, the relationship between Hungary's demographic characteristics and asset class returns will be examined by reviewing previous academic and policy studies through conducting a regression analysis of bond yields and P/E ratio of BUXIndex related to demographic variables.

\section{MOST IMPORTANT RESULTS}

The connection between stock prices and demographic trends is impacted by the life cycle theory of asset accumulation/decumulation and portfolio choice. In Hungary, the younger adults between 36 and 45, and the classic middle-aged individuals are in their peak savings years and invest heavily in stocks, driving up stock prices. The old-aged individuals decumulate assets and sell stocks to finance their retirement, depressing stock prices. In addition, the investors become more risk-averse and prefer fewer holdings of stocks as they grow older. The Middle/Old ratio and the $\mathrm{BUX} \mathrm{P} / \mathrm{E}$ ratio have a strong positive correlation during the period 1995-2020. The bond yields show a similar connection with the Yuppie/Nerd ratio. The results of demographic variables predicting bond-yields are strong and proving the international patterns.

\section{RECOMMENDATIONS}

The paper highlighted that the demographic variables are not only appropriate for socio-demographic analysis since the members of the different age groups have their own consumption, saving and investing characteristics that can have an impact on the asset prices besides other commonly used parameters.

Keywords: ageing, demography, asset pricing, price per earnings

Acknowledgements: This article was supported by EFOP3.6.116201600004 that has been entitled 'Comprehensive developments at the University of Pécs for smart specialization'. (Project element 'Decisionmaking at older ages', topic no. 11)

DOI: 10.15170/MM.2021.55.KSZ.02.03 


\section{INTRODUCTION}

Hungary is experiencing one of the fastest demographic transitions in Europe. Due to the continued extension of longevity and the steep decline in fertility rate, the size and percentage of the elderly population(i.e., aged 65 and above) rapidly increased during the last decades. The UN categorizes the degree of population aging into three phases. Suppose the elderly represent at least 7 percent of the population. In that case, it is considered an "aging society", if they represent at least 14 percent, it is an "aged society", where if elderly represent 20 percent or more, it is called a "super-aged society". Hungary became an agingsociety during the second world war (1941-1942), it took almost 50 years to double the proportion of the elderly population, and the nation became an aged society officially in 1995. The nation has been aging even faster since then. According to recent statistical data, the elderly represented $19.88 \%$ of the population in 2020 (HCSO 2021). It is expected that Hungary will enter the super-aged phase in 2021/2022, as the Ratkó generation reaches retirement age (born in the 1950s) and gets older. ${ }^{1}$

The growth of the population, the population factor in general, influences most of the global megatrends. While it was considered one of the major driving forces for economic growth in the 20th century, it has become the greatest risk factor for the socio-economic landscape. In this study, the relationship between Hungary's demographic characteristics and asset class returns will be examined, based on official statistics available through the Hungarian Central Statistical Office, through international statistical data provided by Statista, by reviewing previous academic and policy studies through conducting a regression analysis. Regarding asset classes, the particular focus of the study is stock and bond.

The paper is organized as follows. In the upcoming section of the paper first, the significant findings of relevant literatures will be discussed. After this summary the chosen dataset will be introduced dividing it to demographical and asset based groups. The paper continues with the current status of the Hungarian demography and turns this into the empirical analysis of asset returns and asset prices. At the end conclusion is drown and further research directions are addressed.

\section{LITERATURE REVIEW}

After reviewing the existing international and Hungarian literature exploring the connection between demographic factors and asset returns or asset prices, two broad categories were identified. First, papers examine the effects of population dynamics on asset returns, and there is a group concentrating on the linkbetween asset returns and demographic features.

According to Holzmann (2005), ageing as a demographic transition is present in developed countries worldwide. In these countries, the growing life expectancy is joined to a falling fertility rate that leads to alow (or negative) population growth and an increasing share of the old-age population.

The first major group of papers considers the linkage between demographic factors and asset returnsbased on the lifecycle investment hypothesis (Modigliani \& Brumberg 1954). According to the hypotheses, people generally borrow at a young age, accumulate at middle age, and decumulate at old age to finance retirement. The changing proportion of these age intervals among the total population changes asset accumulation trends and will affect asset prices. With an increase in the population's average age, asset accumulation and decumulation patterns are likely to differ significantly from the past. The stock market should rise, while the housing market should decline as people live longer. Asset allocation is also influenced by the level of risk aversion (risk premia) of the individual investors and can rise with age (Bakshi \& Chen, 1994).

If we look at the main findings related to the stock market, the following researchers provided the most commonly cited papers:

- Ang \& Maddaloni (2003) investigated the link between demographic changes and equity risk premium across the G5 countries. They proved a connection in the demographic factors of the average age of the population above 20 years, the fraction of adults over 65 , and the proportion of the population working ages 20-64 years.

- Maurer (2011) argues, based on US data, that higher fertility and/or greater longevity resultin a higher equity risk premium, while lower fertility and/or lesser longevity results in a lower equity risk premium. Davis and Li (2003) analyzed the OECD countries and concluded that real stock prices are positively affected by the proportion of the population aged $20-39$ and $40-64$, increasing 
prices by $2 \%$ to $3 \%$ for each $1 \%$ increase in either of these population proportions.

- Brooks (2006) investigated the impact of age shares. Using data from 16 developed countries, his findings show that an increase in the share of the population under age 35 depresses stock prices, increasing the share of the population age 65 and older. Park (2010) found similar results based on G5 data, while Bae (2010) proved the phenomena based on US data.)

- Geanakoplos et al. (2004) are dealing with the price-earnings ratio in their study, and using US stock market data, they suggested, that price-earnings (PE) ratios move proportionally with the ratio of middle-aged to young adults.

- Roy et al. (2012) claim that the link between stock prices and demographic trends is impacted by the life cycle theory of asset accumulation/decumulation and portfolio choice. They were the first to construct and compute a ratio of the middle-aged population to the old-age population, known as the Middle/Old ratio to explain the stock index's price-earnings ratio.

- Poterba (2004) used the dividend yield as a dependent variable. His results show that the population share between the ages of 40 and 64 has a positive and significant correlation with the price-per-dividend ratio. Favero et al. (2011) predicted a negative correlation between the proportion of middle-age to young population ratio and the dividend yield).

When turning to the bond markets and especially to bond yields, the following findings were used in this research:

- Davis \& Li (2003) analyzed real bond yields based on three demographic intervals. The 40-64 age coefficients are significant and negative in all OECD countries, while the 20-39 age interval is significantly positive, increasing the yield.

- Poterba (2004) found the most substantial correlation between his demographic factors andT-Bill returns.

- Roy et al. (2012) had the most significant effect on this study when choosing to regress 10-year government bond yields on the Yuppie-Nerd ratio. They found that bond yields tend to go up when the Yuppie/Nerd ratio rises and vice versa.

Some studies show the misleading consequences while looking only at the aggregate popula- tion, aggregate labor force, or even $65+$ aged people based on past trends. Unprecedented improvements in life expectancies have been accompanied by changes in behavior over the life cycle. School entry age, labor market entry age, age at marriage, age at child-bearing and retirement age differ across countries and relative to similar cohorts a decade ago. In general, people are spending more years in education, entering the labor force later, delaying marriages and child-rearing, and enjoying longer and uncertain post- retirement periods.

\section{DATA AND METHODS}

A wide range of demographic factors could involve an analysis that tries to capture the link between demography and asset characteristics. Previous studies were using different age intervals, working-age factors, and other demographic factors. This study defines commonly used age intervals (young, middle age, and old age) and their related ratios, like the population aged $20-39$ as a percent of the total, the population aged 40-64 as a percent of the total, and population above 65 as a percent of the total. Ten-year age intervals were deployed (36-45; 45-56; 56-65). Specific ratios like the ,yuppie-nerd" ratio, which is the number of the 20 to 34 -year-olds to the number of the 40 to 54 -yearolds were connected to asset returns, and other factors include total population, population growth, life expectancy, mortality, average age, median age, gender in the adult population, and fertility. All of these are considered in this analysis as independent variables.

From the dependent variables side, stock market related, bond market related, and housing market-related factors can be chosen. The stock market stock price indices, price-to-earnings ratios, returns, and market structure need to be analyzed.

\section{Demographical Data}

In the following section, we attempt to review demographic trends and related ratios to examine the possibleconnection between asset prices and demographic patterns. At first, we take the core demographic indicators into account, such as fertility rate, old-age dependency ratio, population growth and life expectancy at birth.

Fertility rates are declining throughout the world, and the decline is faster for less developed regions than the more developed regions. The less developed regions have higher fertility rates and younger and faster-growing populations compared 
to the more developed regions. The more advanced countries have low population growth, leading to low labour force growth and GDP growth. They have also experienced significant life expectancy improvements, leading to more extended and more uncertain post- retirement periods. In the ageing societies, there are more and more elderly people and fewer children whichis in accordance with the old-age dependency ratio that is defined as the ratio of number of old people (65years or more old) compared with the number of people of working-age (15-64 years). The old-age dependency ratio indicates the burden of the ageing population on government finances. It tends to increase age-related government expenditures on pensions, health care, and long-term care.

We identified the same phenomenon in the case of the Hungarian population. The fertility rate starteda steep decline from 1992 until the end of the $90 \mathrm{~s}$. The total fertility rate was below 1.5 between 1996 and 2017 (Figure 1). According to Kapitány and Spéder (2012), if this tendency continues, the Hungarian population will halve every 45 years. The population trend is unpromising because there is no population growth after the $1980 \mathrm{~s}$, and the population decline was the strongest in the late 1980s. One reason for this negative tendency is a natural process, since fewer children were born in the last decades than the numberof people who died in the same period. There is a connection between the low total fertility rate and the declining population because the number of childbearing aged women also decreases. Emigration contributes to this demographic trend, as well.

Figure 1. Core demographic indicators of Hungary
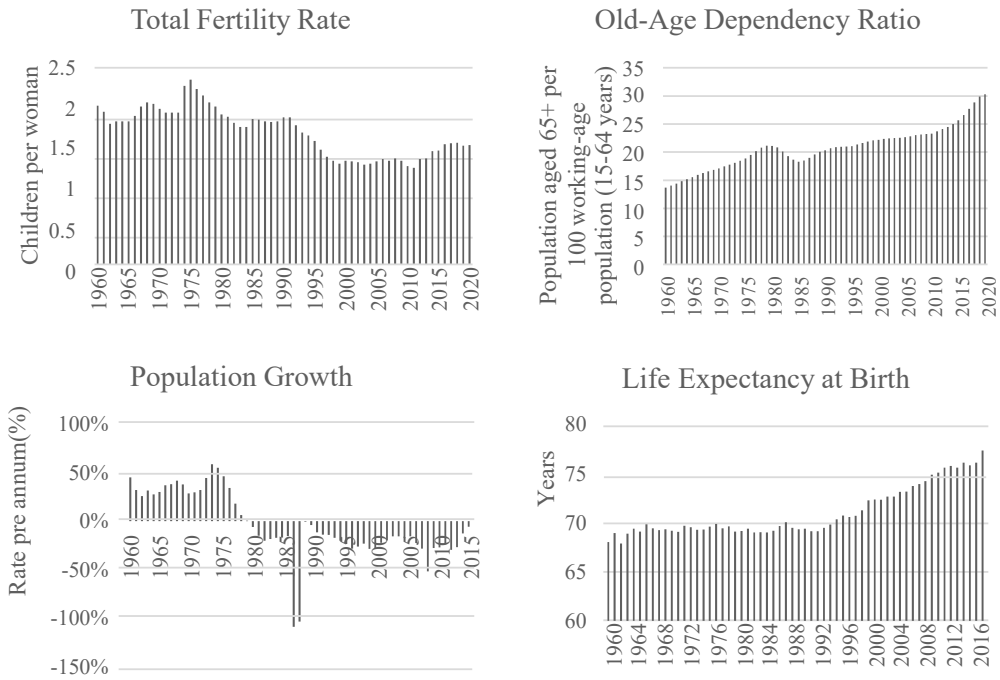

Source: Own compilation according to HCSH (2021), World Bank (2018a,b, 2019c)

Regarding age. If we look at the life expectancy at birth over several decades, the value has risen and even reached an exceptionally high value in 2019. However, if we review the data from the last decade, there is virtually a stagnation between 2013-2018.

In the case of Hungary, the old-age dependency ratio shows a growing tendency from the middle of the 1980s. Figure 2 shows the annual number of live births in Hungary and the year in which they turn 65 . The Ratkó kids refer to those born during 1951-53 (illustrated by the shaded area). 75.9 million babies wereborn during this period. The oldest baby boomers started retiring from 2019 onwards. 
Figure 2. The annual number of live births in Hungary and the year they turn 65

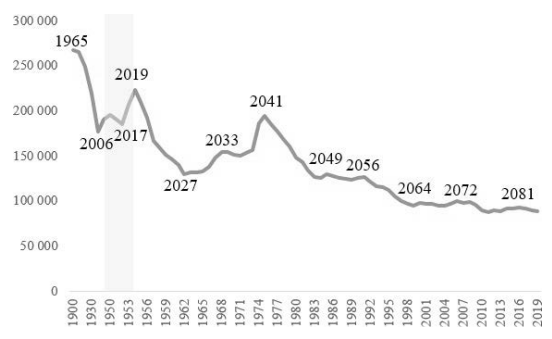

Source: own compilation according to HCSH (2021)

In the first half of the $20^{\text {th }}$ century, mortality increased due to the First and Second World War, simultaneously fertility declined. Population significantly increased first in the 'Ratkó-era' in the 1950s, and then the following remarkable increase was brought by the 'Ratkó grandchildren' in the 1970's. The children of the 'Ratkó-Era' started to retire from 2015 onwards and there has been a huge increase in the number of retirees, which could lead to labor shortages in some areas and a greater burden on the active age group. A similar situation is expected 20 years from now, when the Ratkó grandchildren will retire.

The median age of population in Hungary has increased from 1960 to 2020 and reached 43.3 years in 2020 (Figure 3). The old-age dependency ratio shows the same tendency, rising from 33.6 people aged over 65 years per 100 people aged 15-64 years in 1960 to 42.8 people aged over 65 years per 100 people aged 15-64 years in 2020 .

Figure 3. The median age of the Hungarian population between 1960 and 2019

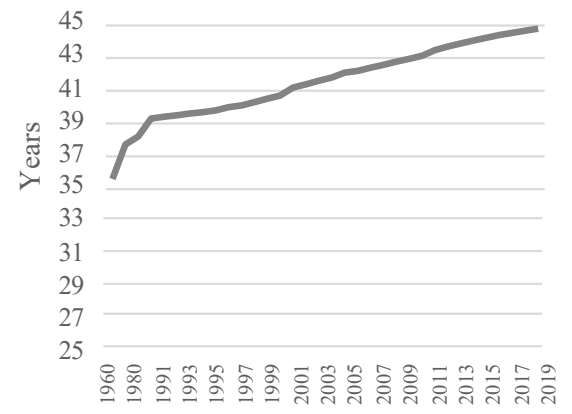

Source: own compilation according to Statista (2021)
As the median age, the old-age dependency ratio shows an increase that can be explained by looking at a longer livespan. The life expectancy of men and women has risen in the past century and the tendency continued in the last two decades (Figure 4). This growth relates to the average effective age of the Hungarian labour market exit. According to Sauré \& Zoabi (2012), the Hungarian male workingpopulations' average effective age of retirement was 58.3 years (female: 55.8 years) in 2000 . OECD (2017) examined this value for five years of 2011-2016 and found that the average effective age of men's labour exit is 63.6 years, which is 0.6 years higher than the normal pensionable age ${ }^{2}$ of men. Exhibit shows that women's life expectancy is higher than men's in Hungary, although the average effective age of retirement is lower (60.7 years in 2016) but showed a growing tendency from 2000 to 2016. The increase in the average effective age of retirement is mainly due to the growing general retirement age.

Figure 4. Life expectancy in Hungary from 1900 until 2019

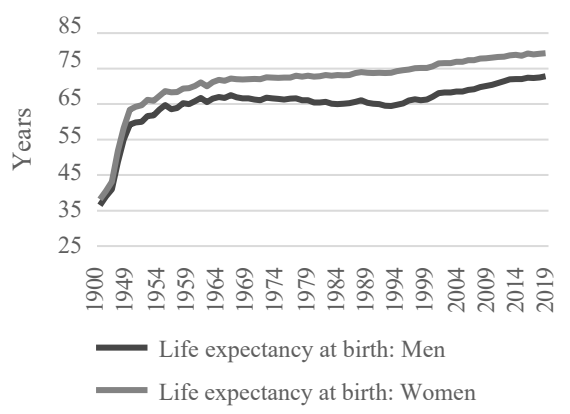

Source: own compilation according to World Bank (2018b)

Figure 5 and Figure 6 reflect the age distribution of the population of Hungary. Two ratios will be used to explain variations in asset prices. The two ratios are the Middle/Old ratio (40-49/ 60-69-yearolds) and Yuppie/ Nerd ratio (20-34/ 40-54-yearolds). 
Figure 5. The Middle/Old ratio of Hungary

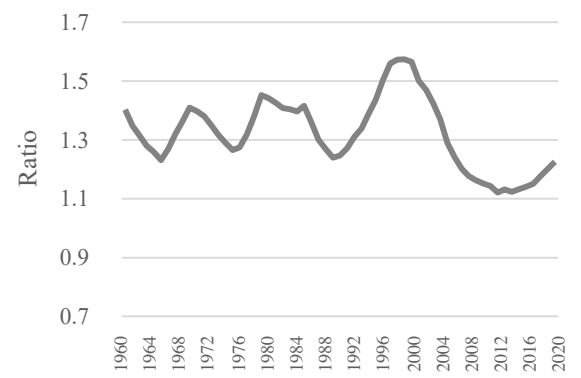

Source: own compilation according to HCSO (2021)

Figure 6. The Yuppie/Nerd ratio of Hungary

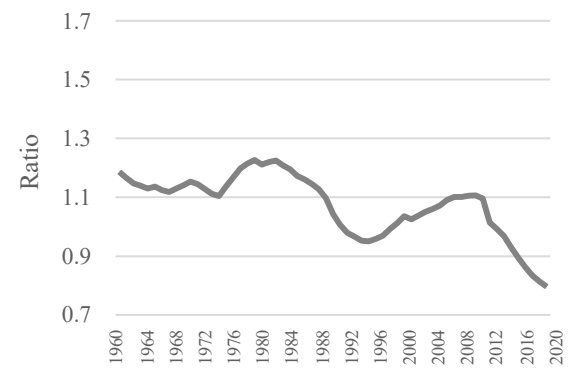

Source: own compilation according to HCSO (2021)

The Middle/Old ratio started to decline because of an increase in the number of old people after the 1990 s, reaching its lowest value at the beginning of the 2010s. Yuppies reflect the young and reckless individuals' and the middle-aged one's characteristics. They are more likely to borrow to buy real estates and cars, whilenerds save and invest more. Research findings suggest that development of these ratios could have an effecton bond yields.

\section{DEMOGRAPHIC FACTORS AND ASSET CHARACTERISTICS}

According to their age characteristics, people face different financial issues, problems, challenges during their lifetime, and use various financial instruments to achieve their various goals. Young adults start to work in the labour market, earn their first labour income and then borrow money to reach their life goal.

Middle-aged adults can earn more and they have the opportunity to save money. Over the lifecycle, the income typically grows with age up to retirement years (Easterlin et al. 1993).

In connection with the lifecycle model, the average income and expenditure of the Hungarian households were analyzed related to the available data from the previous two years of the research (2018-2019) (Figure 7). The households' income grew from the young age to the middle age, culminated in the age group of 55-64, and in the old age started to decline. The expenditures of Hungarian households follow the same pattern as the net income in the different age groups. According to the diagram, the net income per capita increased from 2018 to 2019, but the level of expenditure in 2019 is the same as the net income (per capita) in 2018 at a rough estimate. 
Figure 7. Annual per capita net income and expenditure by the age group in Hungary (2018-2019)

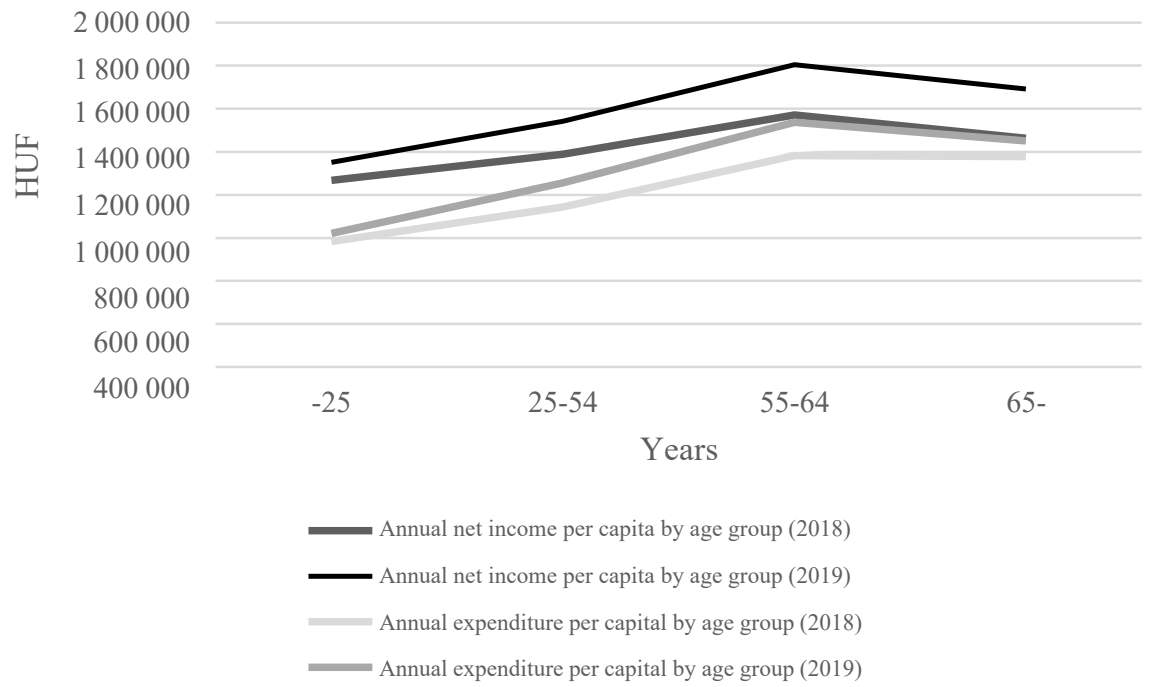

Source: own compilation according to HCSO $(2019 a, b)$

The average net worth of the Hungarian households does not show the same trend as the net income, because it culminates at age 46-55, declines after 55, while decreases sharply after the age 75 (Figure 8).

\section{Figure 8. The average net worth of Hungarian} households by age, 2017

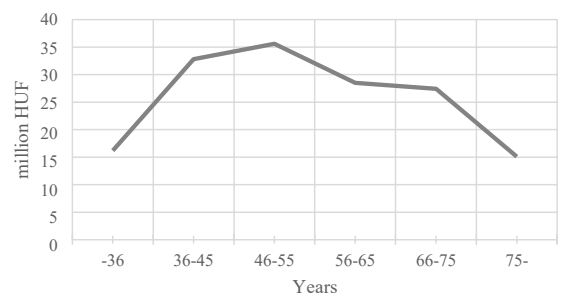

Source: own compilation according to MNB (2017)
The households' net worth contains different instruments which are not considerably different across the age groups. The retirement age households' wealth contains less financial instruments. Table 1 shows the financial asset holdings of the Hungarian households by age in 2017. According to the MNB (2017), the proportion of households with bank accounts and bank deposits decreases with age, while the number and scope of financial investments increases. The households diminished debts and private money loans by age. Half of the households with a household head older than 75 years have a bank account, bank deposit and 5\% of them had securities and nearly $2 \%$ of them had investment fund shares. 
Table 1. Percentage of households with different financial instruments by the age of household head (2017, in percentage)

\begin{tabular}{|c|c|c|c|l|l|l|l|l|l|}
\hline $\begin{array}{l}\text { Age of } \\
\text { house- } \\
\text { hold } \\
\text { head }\end{array}$ & $\begin{array}{l}\text { Capital } \\
\text { invest- } \\
\text { ment }\end{array}$ & $\begin{array}{l}\text { Transaction } \\
\text { account, } \\
\text { bank } \\
\text { deposit }\end{array}$ & $\begin{array}{l}\text { Secu- } \\
\text { rities }\end{array}$ & $\begin{array}{l}\text { Invest- } \\
\text { ment } \\
\text { fund } \\
\text { shares }\end{array}$ & $\begin{array}{l}\text { Private } \\
\text { money } \\
\text { loan }\end{array}$ & $\begin{array}{l}\text { Insurance, } \\
\text { pension } \\
\text { claim }\end{array}$ & $\begin{array}{l}\text { Sole } \\
\text { prop- } \\
\text { rietor- } \\
\text { ship }\end{array}$ & $\begin{array}{l}\text { Number } \\
\text { of house- } \\
\text { holds, } \\
\text { thousands }\end{array}$ \\
\hline-35 & 9 & 92.7 & 6.1 & 7.5 & 15.2 & 12.9 & 51.4 & 5 & 599 \\
\hline $36-45$ & 10.1 & 94.9 & 8.6 & 9.8 & 13.3 & 24.9 & 58.1 & 7.2 & 795 \\
\hline $46-55$ & 11.3 & 89.6 & 7.3 & 10 & 11.1 & 26.8 & 45.3 & 6.8 & 749 \\
\hline $56-65$ & 9.2 & 85.1 & 7.9 & 6.9 & 7.3 & 15.4 & 36.7 & 7.2 & 890 \\
\hline $66-75$ & 4.5 & 69.3 & 7.4 & 5.3 & 5.6 & 2.3 & 18.3 & 2.8 & 671 \\
\hline $76-$ & 1.1 & 51.1 & 5.2 & 1.9 & 2.4 & 0.4 & 5.8 & 0.2 & 424 \\
\hline
\end{tabular}

Source: $M N B$ (2017)

The percentage of families holding any financial assets increases with age, but in the case of the value of holdings, the value of the financial instrument decreases reaching the retirement age. This financial instrument value has its peak at the age of 36-45 years, indicating that the decumulation of financial assets earlier than international research results suggests (MNB, 2017) (see Table 2).

Table 2. The average value of different instruments per households by the age of household head (2017, in million HUF)

\begin{tabular}{|c|c|c|l|l|l|r|r|r|r|r|}
\hline $\begin{array}{l}\text { Age of } \\
\text { house- } \\
\text { hold } \\
\text { head }\end{array}$ & $\begin{array}{l}\text { Total } \\
\text { assets }\end{array}$ & $\begin{array}{l}\text { Fixed } \\
\text { assets }\end{array}$ & $\begin{array}{l}\text { Finan- } \\
\text { cial } \\
\text { instru- } \\
\text { ments }\end{array}$ & $\begin{array}{l}\text { Transaction } \\
\text { account, } \\
\text { bank } \\
\text { deposit }\end{array}$ & Debts & $\begin{array}{l}\text { Total } \\
\text { income }\end{array}$ & $\begin{array}{l}\text { Labour } \\
\text { income } \\
\text { repre- } \\
\text { neurial } \\
\text { income }\end{array}$ & $\begin{array}{l}\text { Con- } \\
\text { Pension } \\
\text { sumption } \\
\text { expendi- } \\
\text { ture }\end{array}$ \\
\hline-35 & 12.9 & 9.2 & 3.7 & 1.2 & 2 & 3.9 & 3 & 0.3 & 0.1 & 1.6 \\
\hline $36-45$ & 20.2 & 12.4 & 7.8 & 1.4 & 2.7 & 4.4 & 3.2 & 0.3 & 0.1 & 1.7 \\
\hline $46-55$ & 19.9 & 14.8 & 5.1 & 1.4 & 1.9 & 4.2 & 3.3 & 0.2 & 0.3 & 1.6 \\
\hline $56-65$ & 18.2 & 14.2 & 4.1 & 1.7 & 1.2 & 3.2 & 1.6 & 2 & 1 & 1.5 \\
\hline $66-75$ & 13.8 & 11.6 & 2.2 & 1.1 & 0.4 & 2.3 & 0.4 & 0.1 & 1.7 & 1.3 \\
\hline $76-$ & 9.8 & 8.6 & 1.2 & 0.7 & 0.1 & 1.8 & 0.1 & 0 & 1.6 & 1.2 \\
\hline
\end{tabular}


Table 3 shows more clearly the trend of investment in stocks over the life cycle in Hungary. The percentageof families holding stock (direct or indirect) in 2017 increased from 5\% at age below 35 to $46.4 \%$ at the age group of $45-54$ and then declined to $3.6 \%$ at the age above 65 . The average value of unlisted shares and other equity holdings peaked at the age group of $36-45$, stagnated at $46-55$ and declined in old age above 56. This finding in part confirms the theory that the middle-aged households are net buyers of stock and the elderly net sellers. Only in part because as the case related the overall financial instrument holdings, the peak occurs at a younger age between 36 and 45 . This is also the age group where households hold the highest wealth (real and financial).

Table 3. Unlisted shares and other equity holdings by age in Hungary, 2017

\begin{tabular}{|c|c|c|}
\hline $\begin{array}{l}\text { Age of } \\
\text { household } \\
\text { head }\end{array}$ & $\begin{array}{c}\text { \% of Households with unlisted shares } \\
\text { and other equity by the household } \\
\text { head's age }\end{array}$ & $\begin{array}{c}\text { Average value of unlisted shares } \\
\text { and other equity holdings } \\
\text { (million HUF) }\end{array}$ \\
\hline-36 & 5 & 35.6 \\
\hline $36-45$ & 37.9 & 105.5 \\
\hline $46-55$ & 46.4 & 102.8 \\
\hline 56-65 & 6.4 & 15.8 \\
\hline 65- & 3.6 & 32.1 \\
\hline
\end{tabular}

Source: $M N B$ (2017)

In addition to the qualitative analysis of the Hungarian demographic characteristics, a quantitative assessment of the relationship between demographic factors and the stock and the bond market wasconducted. First related to asset prices, followed by yield and return related demographic issues. The link between stock prices and demographic trends is impacted by the life cycle theory of asset accumulation/decumulation and portfolio choice. Younger individuals might borrow for longer due to late entry into the labour market. Middle age groups, accumulating assets, might extend beyond the 50-year-oldsbecause they now face longer and more uncertain retirement periods and may choose to save for longer.Early retirees might continue to save not only as bequests for their children but also because of uncertaintiespertaining to the length of the post-retirement period or to support their parents who are now living longer. Hence, accumulation and decumulation of assets are likely to occur in a pattern different from what hasoccurred in the past and there may be a need to redefine age ranges used traditionally to explain asset prices. In Hungary, as it was shown earlier, the younger adults between 36 and 45, and the classic middle-aged individuals are in their peak savings years and invest heavily in stocks, driving up stock prices.
The old-aged individuals decumulate assets and sell stocks to finance their retirement, depressing stock prices. In addition, the investors become more riskaverse and prefer fewer holdings of stocks as they grow older.

The link between yields and returns and demographic trends. Next, the relationship between the 10-year government bond yield and the Yuppie/Nerd ratio from 1999 to 2020 was examined. As Figure 9 shows, the bond yields increased when the Yuppie/ Nerd ratio started to increase and the same tendency can be observed in the case when bond yields declined. The Yuppie/Nerd ratio and the 10-year government bond yield have a strong positive correlation, at 0.85 , during the analyzed period. Figure 9 also includes the projections of the Yuppie/Nerd ratio from 2020 to 2025 . The ratio started to decline in 2012 and this tendency is expected to continue, although the forecast shows a higher decrease in the bond yield than theYuppie/Nerd ratio. 
Figure 9. Yuppie/Nerd ratio and 10-year government bond yield

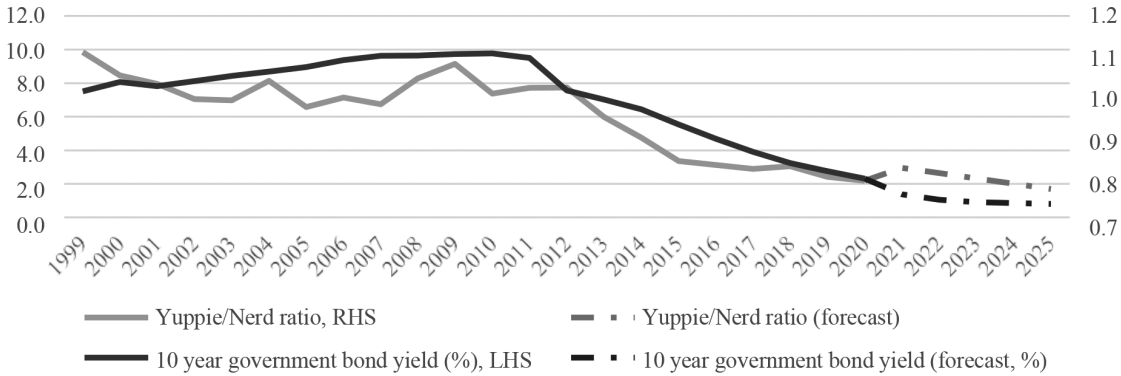

Source: own compilation

Turning to the stock markets, the Price per Earnings $(P / E)$ ratio of the Hungarian stock index was collected and analyzed related to specific demographic variables suggested by the literature. The Hungarian capital market was launched in 1990, with the 41 founding members of Budapest Stock Exchange having only one equity, named IBUSZ. A few years later in 1995, the listing of BUX Index was started and in the same year, the derivative market became available for investors (Korányi \& Szeles 2007, Kaszuba 2010).

As concluded earlier, the financial decisions of middle-aged Hungarian individuals seem to be of interest to the return related analysis. This age group invests the greatest extent of its saving into financial instruments, the head of household from these age intervals becomes more risk-averse with age and starts to focus on saving for retirement. Based on the work of Goyal (2004) the ratio of the middle-aged population to the old-age population, known as the "Middle/Old ratio," was called to explain the price-earnings ratio of the Budapest stock index (BUX). According to the findings of the mentioned paper, they are expected to correlate positively. The Middle/Old ratio and the BUX P/E ratio have a strong positive correlation, at 0.69 , during the period 1995-2020 as shown in Exhibit. The demographic projections for the Middle/Old ratio for the period between 2020 and 2026 suggest an expected growth of the Hungarian Middle/ Old ratio. Until the Middle/Old ratio is expected to increase, the BUX Index's $\mathrm{P} / \mathrm{E}$ ratio is expected to decline (Figure 10).

Figure 10. BUX Index $\mathrm{P} / \mathrm{E}$ ratio and Middle/Old ratio in Hungary

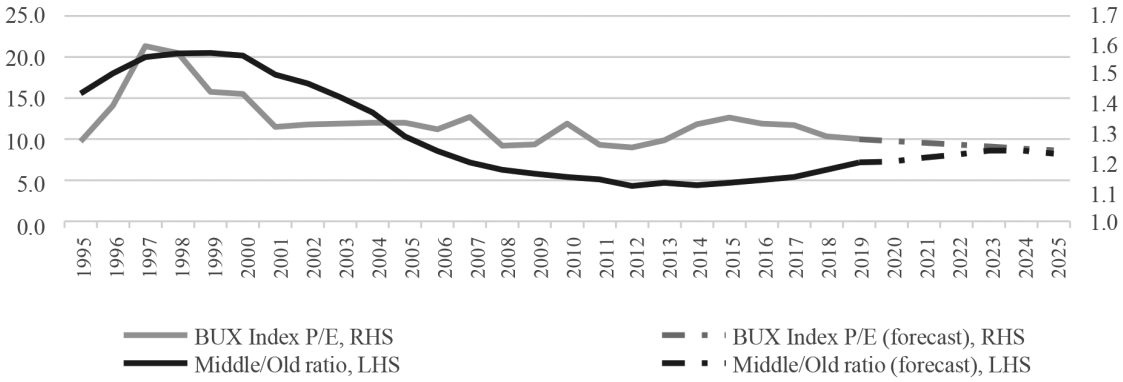

Source: own compilation 
It needs to be stated at this point of the research, that forecasts based on single demographic age variables do not need to be taken too seriously because of other important factors through the business cycle, which may lead to much higher P/E ratios such as technological breakthroughs, innovation, cheaper resources, and efficient labour practices as well as management.

The level of stock market participation can explain the correlation between the two ratios, therefore the saving or dissaving behaviour can affect the stock market. A possible reason for the work out of the relationship can be the level of stock market participation. If most of the investors are actively investing in asset classes such as bonds, their saving/dis-saving behaviour should not affect the stock market significantly. The stock market capitalization as a share of GDP is relatively low in Hungary (Germany had $43.2 \%$ stock market capitalization in 2010 , while it was $138.8 \%$ in the case of the United Kingdom the same year). The relative values of stock and bond market capitalization give us an idea of the relative importance of the two assets for investors and help us understand the links between investor characteristics and asset prices. As Figure 11 shows, the Hungarian public bond market capitalization is higher than the stock market's value, explaining the investors' preferred investment opportunity choices and their characteristics.

Figure 11. Stock and bond market capitalization in the percentage of GDP in Hungary

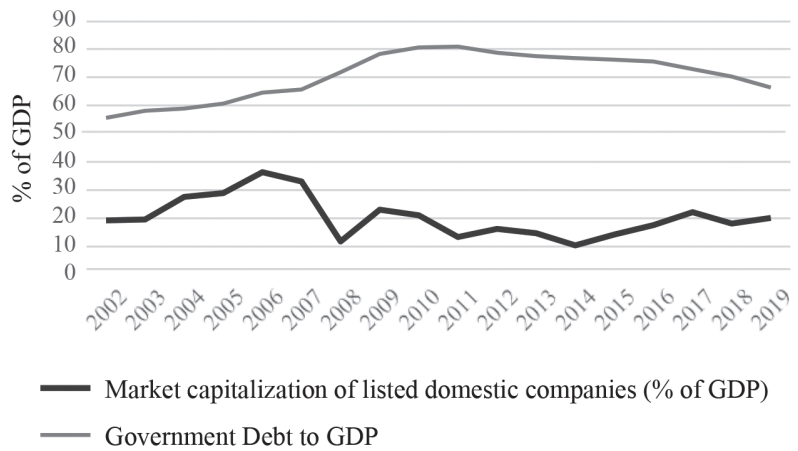

Source: Tradingeconomics.com, World Bank (2019b)

The demographic factors' impact on the Price per Earnings ratio of the BUX Index was analyzed based on the literature. The connection was examined with bivariate regression, where the dependent variable $R_{i, t}$ was the $\mathrm{P} / \mathrm{E}$ ratio and the chosen demographic factors $Z_{j, t}$ (annual number of live birth, total fertility, life expectancy at birth median age, population growth, old-age dependency and Yuppie/ Nerd ratio) were single independent variables. All variables are on an annual basis and available from 1995 to 2020 . The constraint of the model is that the BUX Index was listed for the first time in 1995, which affected the sample size. According to the regression, only one variable, the Middle/Old ratio, predicted a positive, statistically significant relationship with the dependent variable. The bivariate regression:

$$
R_{i, t}=c+\beta_{j} Z_{j, t}+\varepsilon_{i, t}
$$

where $\mathrm{R}_{i, t}$, denotes the real return of asset $i$ in year $t$ was run for each of these demographic variables. The explanatory power of the model in case of having the Middle/Old ratio as an independent variable is $47.9 \%$. After analyzing the $\mathrm{P} / \mathrm{E}$ of the BUX index, the effects of the demographic variables and the components of the interest rates on the nominal 10-year government bond yields were examined the same way. The bivariate regression is the same $\mathrm{R} i, t$, denotes now the 10-year government bond yields for Hungary. According to results, regressing on their respective Yuppie-Nerd ratios (the ratio of the number of 20-34- year-olds to the number of 40-54-year-olds) and, as shown, the age of retirement provides a good regression fit $\left(\mathrm{R}^{2}=62.7 \%\right)$, 
and a positive relationship between these ratios and the 10-year government bond yields. As a result of variance analysis, the model proved to be significant in explaining the variation in 10-year government bond yields.

\section{CONCLUSION}

In this study, Hungary's life cycle theory was applied while exploring the quantitative link between population structures and stock and bond prices and returns. The life cycle changes include longer years in education, delayed marriage and parenthood, school-breaks, college-breaks and career breaks, multiple jobs, phased retirement, caring for children and older parents, and extended retirement periods changes in the behaviour of consumers and investors.

After discussing the main findings of previous research, variables were defined through the state of the art of the Hungarian demography. It reflects a decreasing fertility rate till the 2010 s, which could be a cause of a natural process, since fewer children were born in the last decades than the number of people who died in the same period; and could be the cause of a drastic change in the number of childbearing aged women and in the willingness to start a family as well. In case of the life expectancy, virtually a stagnation can be found, while the oldage dependency ratio shows a growing tendency from the middle of the 1980s. The Middle/Old ratio started to decline because of an increase in the number of old people after the 1990s, reaching its lowest value at the beginning of the 2010s. One of the demographic ratios that were chosen to examine the relationship between asset characteristics and demography is the yuppie/nerd ratio. The yuppies reflect the young and reckless individuals', while the nerds the middle-aged one's characteristics.

According to their age characteristics, people face different financial issues, problems, challenges during their lifetime, and use various financial instruments to achieve their various goals. In connection with this lifecycle model, the average income and expenditure of the Hungarian households were analyzed. The households' income grew from the young age to the middle age, culminated in the age group of 55-64, and in the old age it started to decline. The expenditures of Hungarian households follow the same pattern as the net income in the different age groups. The average net worth of the Hungarian households culminates at the age of 46-55, declines after 55, while decreases sharply after the age of 75 . The percentage of families hol- ding any financial assets increases with age, but in the case of the value of holdings, the value of the financial instrument decreases reaching the retirement age.

In addition to the qualitative analysis of the Hungarian demographic characteristics, a quantitative assessment of the relationship between demographic factors and the stock and the bond market was conducted.

The paper examined the relationship between the 10-year government bond yield and the Yuppie/ Nerd ratio, which proved to have a strong positive correlation, at 0.85 , during the analyzed period. Regarding the stock markets, the Price per Earnings $(\mathrm{P} / \mathrm{E})$ ratio of the Hungarian stock index was collected and analyzed related to specific demographic variables suggested by the literature. Based on the literature review the ratio of the middle-aged population to the old-age population, known as the "Middle/Old ratio" was called to explain the price-earnings ratio of the Budapest stock index (BUX). According to the findings of the mentioned paper, they are expected to correlate positively $(=0.69)$.

The analysis of the asset prices and asset returns starts with a relationship analysis and concluded in a regression analysis of bond yields's and $\mathrm{P} / \mathrm{E}$ ratio's related to demographic variables. These results were used to study the predictability of yields for bond markets and $\mathrm{P} / \mathrm{E}$ ratios for stock markets. The results of demographic variables predicting bond-yields are strong and prove the international patterns.

Overall, the demographic characteristic of Hungary provided a good set of variables to analyze the asset prices and asset returns. For future research, the methods applied could be adjusted to dealing with specific demographic issues and refining results about the relationship between ageing and asset returns, and also providing a better approximation of the predicting power of these variables. 


\section{REFERENCES}

Ang, A. \& Maddaloni, A. (2003), "Do Demographic Changes Affect Risk Premiums? Evidence fromInternational Data", The Journal of Business, 78(1), 341-380 DOI: 10.1086/426528

Bakshi, G. S. \& Chen, Z. (1994), "Baby Boom, Population Aging and Capital Markets", The Journal ofBusiness, 67(2), 165-202 DOI: $10.1086 / 296629$

Bae, Y. (2010), "Stock Prices and Demographic Structure: A Cointegration Approach", Economics Letters, 107(3), 341-344 DOI: 10.1016/j. econlet.2010.02.017

Brooks, R. (2006), "Demographic Change and Asset Prices", In: Kent, Ch., Park, A., Rees, D. (Eds.), Demography and Financial Markets, Reserve Bank of Australia, 235-261

Davis, E. P. \& Li, C. (2003), Demographics and Financial Asset Prices in the Major Industrial Economies, Economics and Finance Discussion Papers 03-07, Brunel University, http://ephilipdavis.com/demog-assetp8.pdf (Last download: 2021.01.10)

Easterlin, R. A., Macunovich, D. I. \& Crimmins, E. M. (1993), "Economic Status of the Young and the Old in the Working-age Population, 1964 and 1987', In: Bengston, V. L., Achenbaum, W. A. (Eds.), The Changing Contract Across Generations, Newbury Park, CA: Sage, 67-86

Favero, C. A., Goluklu, A. E. \& Tamoni, A. (2009), "Demographic Trends, the Dividend-price Ratio, andthe Predictability of Long-Run Stock Market Returns, Journal of Financial and Quantitative Analysis, 46(5), 1493-1520 DOI: 10.1017/s0022109011000329

Geanakoplos, J., Magill, M. \& Quinzii, M. (2004), "Demography and the Long-Run Predictability of theStock Market", Brookings Papers on Economic Activity, 2004(1), 241-307 DOI: 10.1353/ eca. 2004.0010

Goyal, A. (2004), "Demographics, Stock Market Flows, and Stock Returns", Journal of Financial and Quantitative Analysis, 39(1), 115-142 DOI:10.1017/S0022109000003914

Holzmann R. (2005), Demographic Alternatives for Aging Industrial Countries: Increased Total Fertility rate, Labor Force Participation, or Immigration, Bonn: Institute for the Study of Labor, Discussion PaperNo. 1885, http://ftp.iza. org/dp1885.pdf (Last download: 2021.01.14)

Kapitány, B. \& Spéder, Zs. (2012), Demographic Portrait of Hungary 2012: Report on the Conditions of the Hungarian Population, Fertility.
Budapest: Demographic Research Institute, Hungarian Central Statistical Office, 31-43

Kaszuba, S. (2010), "East and Central Europe Stock Exchange Markets in the Ages of Globalization, International Journal of Trade", Economics and Finance, 1(1), 89-92 DOI: 10.7763/ IJTEF.2010.V1.17

Korányi, G. T. \& Szeles, N. (2007), History of Budapest Stock Exchange from 1990, In: Budapest Stock Exchange: Birth of an Exchange, Budapest, https://www.bse.hu/bse30/BSE-history-from-1990 (Last download: 2021.01.14)

Maurer, T. A. (2011), “Asset Pricing Implications of Demographic Change", 24 $4^{\text {th }}$ Australasian Finance andBanking Conference 2011, https:// ssrn.com/abstract=1836483, (Last download: 2021.01.09) DOI: 10.2139/ssrn.1836483

Magyar Nemzeti Bank (MNB) (2017), A háztartási szektor pénzügyi megtakaritásai mikro- és makrostatisztikai adatok alapján. Budapest: Magyar Nemzeti Bank Statisztikai Igazgatósága, https:// www.mnb.hu/letoltes/haztartasok-hun-0531. pdf (Last download: 2021.01.12.)

Modigliani. F. \& Brumberg, R. (1954), "Utility Analysis and the Consumption Function: An Interpretation of Cross-Section Data", In: Kurihara, K. K. (ed.), Post-Keynesian Economics, New Brunswick: Rutgers University Press, 388436

Organisation for Economic Cooperation and Development (OECD) (2017), Pensions at a Glance 2017: OECD and G20 Indicators, Paris: OECD Publishing, DOI: 10.1787/19991363

Park, C. (2010), "How Does Changing Age Distribution Impact Stock Prices? A Nonparametric Approach", Journal of Applied Econometrics, 25(7), 1155-1178 DOI: 10.1002/jae.1101

Poterba, J. M. (2004), The Impact of Population Aging on Financial Markets, Cambridge, Mass.: NationalBureau of Economic Research, https:// www.nber.org/papers/w10851 (Last download: 2021.01.13) DOI: 10.3386/w10851

Roy, A., Punhani, S. \& Shi, L. (2012), How Demographics Affect Asset Prices Global Demographics and Pensions, CreditSuisse, https://plus. credit-suisse.com/rpc4/ravDocView?docid=F2Gn6K (Last download: 2021.01.12)

Sauré, P. \& Zoabi, H. (2012), Retirement Age across Countries: The Role of Occupations, Zurich: Swiss National Bank, http://apps.eui.eu/Personal/JMF/PhilipSaure/Retirement SNB.pdf DOI: 10.2139/ssrn.1940452 (Last download: 2021.01.14) 
Hungarian Central Statistical Office (2021): Népesség, népmozgalom (1941-), https:// www.ksh.hu/docs/hun/xstadat/xstadat_eves/i wnt001c.html (Last download: 2021.01.22)

Statista (2021), Hungary: Average Age of the Population From 1950 to 2050 (median age in years), https://www.statista.com/statistics/332519/ average-age-of-the-population-in-hungary/ (Last download: 2021.01.22)

Hungarian Central Statistical Office (2021), Magyarország népességének száma nemek és életkor szerint. https://www.ksh.hu/interaktiv/korfak/orszag.html (Last download: 2021.01.22)

Hungarian Central Statistical Office (2019a), A háztartások életszínvonala. https://www.ksh. hu/docs/hun/xftp/idoszaki/hazteletszinv/2019/ index.html (Last download: 2021.01.22)

Hungarian Central Statistical Office (2019b), Annual per Capita Expenditure by COICOP, Income Deciles, https://www.ksh.hu/docs/eng/ xstadat/xstadat annual/i zhc021a.html (Last download: 2021.01 .22

Tradingeconomics.com: Hungary Private Debt to GDP, https://tradingeconomics.com/hungary/private- debt-to-gdp (Last download: 2021.01.22)

World Bank (2018a), Fertility Rate, total (birth per woman) https://data.worldbank.org/indicator/ SP.DYN.TFRT.IN?locations=HU (Last download: 2021.01 .22$)$

World Bank (2018b), Life Expectancy at Birth, https://data.worldbank.org/indicator/SP.DYN LE00.IN?locations $=\mathrm{HU}$ (Last download: 2021.01.22)

World Bank (2019a), Inflation, GDP deflator. https://data.worldbank.org/indicator/NY.GDP. DEFL.KD.ZG?locations=HU (Last download: 2021.01.22)

World Bank (2019b), Market Capitalization of Listed Domestic Companies (\% of GDP) https://data.worldbank.org/indicator/CM.MKT. LCAP.GD.ZS (Last download: 2021.01.22)

World Bank (2019c), Population Growth (Annual \%) - Hungary, https://data.worldbank.org/ indicator/SP.POP.GROW?locations=HU (Last download: 2021.01.22)
Alexandra Posza, PhD, Associate Professor poszaa@ktk.pte.hu

Vivien Csapi, PhD, Associate Professor csapiv@ktk.pte.hu

University of Pecs,

Faculty of Business and Economics

1 The law and the children born during those years are commonly mentioned as the Ratkó years, and Ratkó kids after AnnaRatkó who served as Minister of Health from 1951 to 1953.

2 Pensionable age is shown for individuals retiring in 2016 and assuming labour market entry at age 20 (OECD, 2017). 